\title{
The Impact of Service Quality Dimensions on Students' Satisfaction: A Study of International Students in Malaysian Public Universities
}

\author{
Abdul Hakeem Alade Najimdeen \\ Kulliyyah of Education, \\ International Islamic University Malaysia, \\ Kuala Lumpur, Malaysia \\ najimdeen22@gmail.com
}

\author{
Ismail Hussein Amzat \\ Kulliyyah of Education, \\ International Islamic University Malaysia, \\ Kuala Lumpur, Malaysia \\ ihussein@iium.edu.my
}

\author{
Hairuddin bin Mohd Ali \\ Kulliyyah of Education, \\ International Islamic University Malaysia, \\ Kuala Lumpur, Malaysia \\ hairuddin@iium.edu.my
}

\begin{abstract}
This study is conducted to examine the relationship between quality service and students' satisfaction based on the perceptions of international students in Malaysian public universities. The questionnaire used was adapted from ServQual and Customer Satisfaction instruments. Using the mean scores, Cronbach Alpha, correlation matrix, and regression analysis, the findings indicated moderate positive perceptions of overall university quality service and satisfaction with a low level of satisfaction for some dimensions of quality service such as empathy and assurance. This gap can be minimized by improving the issues of trust, courtesy, and responsiveness of university service with more focus on the emotional aspects and human connection in delivery service.
\end{abstract}

Keywords: Quality Service, ServQual, Customer Satisfaction, Student Loyalty, Student Mobility, International Students, International Education

\section{INTRODUCTION}

The competitiveness of the global education market and the political and socio-economic changes in developing countries have led international students to look for various available options to pursue their higher learning. The Organization for Economic Co-operation and Development's (OECD, 2015) report outlines the huge size of international education and the growing competition facing not only the well-known international education destinations but also the new hubs. This signals the need for the new educational hubs to develop their higher education service into a world-class standard. It is also necessary for higher education institutions to look into the factors that attract international students and effective ways to build a strong relationship and retain them for academic growth and institutions' economic gains. 
On one hand, Malaysia is considered one of the evolving international hubs in South East Asia. It has responded to the challenges of education by introducing various policies on international education (Abdullah, Abd Aziz, \& Mohd Ibrahim, 2017). As of March 2019, Malaysia hosted 127,583 international students of which $70 \%$ of them were enrolled in private higher education institutions (Stacey, 2019). While this might be considered an indication that the country missed its target of 200,000 international students by 2020, it also shows that there is a need to study the main components that international students themselves consider being the elements of quality education services, especially in public higher institutions.

On the other hand, despite the importance of international students in actualizing the Malaysian internationalization policy, many studies on the quality of service in higher education institutions in Malaysia have not given many considerations to the evaluation of international students and their level of satisfaction toward the university services they received. This gap needs to be filled because satisfying international students will impact their loyalty and, in return, contribute to the establishment of appropriate programs (Thomas, 2011; Abdullah, Abd Aziz, \& Mohd Ibrahim, 2017) that can entice new students, promote quality education, develop and maintain successful long-term relationships between the institutions and the current or former students (Rojas-Méndez et al., 2009; Chandra et al., 2019).

The quality of educational service is important in students' satisfaction and students' continuous patronage. It can be achieved by focusing on delivering top-notch services. Satisfied students may recommend the institution's services to others based on the trust and commitment in the education they have already received (Lien, 2017). Hence, the current study aims to:

1. Explore the level of international students' satisfaction toward quality service in public universities in Malaysia.

2. Determine the relationship between university quality service and international students' satisfaction.

3. Check the impact of quality service dimensions on students' satisfaction.

4. Identify the critical factors and predictors in quality service that contribute most to international students' satisfaction.

\section{LITERATURE REVIEW}

\section{Quality Service}

The concept of quality has its origin in the management literature. It was first introduced by Juran (1974) and later developed by Deming and Edwards (1982). There is no consensus on the definition of quality itself. Most studies on the concept of quality tend to rely on the perspectives of a service provider or the evaluation of the consumer on his overall experience and superiority of the product and service (Zeithaml, 1987; Zammuto et al., 1996; Jain, Aagja \& Bagdare, 2017). The difficulties in measuring and knowing what constitutes the quality and value of a product or service also led marketing companies to rely on their customers' perception and expectation of quality (Borgave, 2012). Perceived quality is related to satisfaction and stems 
from the consumers' comparison of their expectations with their perceptions of performance (Rowley, 1996; Hasan et al., 2008; Kasiri, 2017).

The need to improve products and services led to the birth of various concepts of service quality. Grönroos (1984) and Parasuraman et al. (1985) were credited for their efforts to conceptualize service quality. The latter has been the favorite of many studies because it is based on customers' perception and expectation of quality and different dimensions of what constitutes service quality (Malik, Danish \& Usman, 2010; Kasiri, 2017). According to Oldfield and Baron (2000), the concept of service quality is made up of three significant dimensions: service processes that have something to do with the system of policies adopted by a service provider, interpersonal factors, and physical evidence.

Moreover, while there is an ongoing discussion on whether it is appropriate to treat students like customers in the context of education services, the reality is that there is a difference between "marketization" of education and marketing education because unlike customers students are usually not independent when acquiring products or services as they wish (Clayson \& Haley, 2005; Kasiri, 2017). Students are the main consumers of educational services and treating them as customers can prompt the staff of an educational institution to please their students and treat them right (Aagja \& Bagdare, 2017; Lien, 2017; Ratnasari et al., 2020).

Parasuraman and his colleagues later redefined the Gap model and came up with ServQual (SERVice QUALity) in 1988 based on Gap 5 (Perception Gap). The original ten dimensions of service quality were decomposed into five dimensions, namely:

- Tangibility: which has to do with the appearance of facilities, equipment, and the organization's personnel.

- Empathy: which is the caring, emotion, and attention given to the customers by the organization.

- Reliability: the ability to perform the promised services accurately and reliably.

- Assurance (including competence, communication, security, credibility, and courtesy): which is the employees' knowledge and ability to inspire confidence and trust.

- Responsiveness: this has to do with the willingness to help customers and provide prompt services.

The findings of various studies in higher education have repeatedly confirmed the usefulness of the Gap model and its ServQual instrument in checking the institutions (providers) performance and students' (consumers) views to improve the quality of educational service of these institutions. As service providers, educational institutions need to identify the key determinants of service quality to improve the quality (Jain, Aagja \& Bagdare, 2017; Shokouhyar, Shokoohyar \& Safari, 2020). 


\section{Customer Satisfaction}

Over the last five decades, customer satisfaction has been in the center stage of discussion due to its importance in the marketing field. In this regard, Cardozo (1965) is credited for his experimental study on the efforts, expectations, and satisfaction of the customer. He stated that in evaluating products, customers use their expectations or previous experiences of an array of products as guidelines, and failure of the provider of a product to measure up to these guidelines can lead to no sale or unfavorable publicity and reactions (Albayrak, 2019). His theory and that of Howard and Sheth (1969) also indicate that consumers tend to exaggerate any differences between their expectations and their evaluations of a product (Ok et al., 2018).

There is no agreed-upon definition for customer satisfaction. Kotler and Clarke (1987) defined it as a feeling of fulfillment from someone who has experienced a certain performance. Westbrook (1981) saw satisfaction as a kind of cognitive appraisal process of comparing between product performance and the previous expectation by customers, while Oliver's (1977, 1980) Expectation Confirmation theory proposed that for satisfaction to be met, its level should arise from the discrepancy between the expected performance and the perceived performance. Oliver also sees satisfaction as a reaction of the customer to a product or performance temporarily and emotionally.

However, looking at the reliance of many studies on expectation and perception when discussing satisfaction, another issue is what constitutes expectation and if it is appropriate to judge a satisfaction level towards a product based on consumers' presumed expectations or if the evaluation should be based only on the customers' experiences after consuming a product (Sun, \& Gao, 2015; Ratnasari et al., 2020). According to Carey, Cambiano and De Vore (2002), satisfaction in educational institutions should focus on the issues of the perceptions and experiences of students during their study. Although the nature of higher education service, modern technologies, and the new mode of communication suggest that most prospective students will have presumed expectations based on recommendations, word-of-mouth, and broadcast media from other satisfied or unsatisfied students. It is considered necessary for higher education institutions to study first what the students expect before their enrollment and what the former and current students considered the elements of university quality service and performance (Lien, 2017; Ratnasari et al., 2020).

\section{University Quality Service and Students' Satisfaction}

In the wake of competitive environments in the education markets and creating a value-based service for consumers with high monetary returns, which is important in the development of national economies, universities are embracing a proper understanding of the determinants of students' satisfaction (Hanaysha, et al., 2011; Chandra et al., 2019) and perceptions of quality that can be different from students to another (Gerson, 1993; Khoo, Ha \& McGregor, 2017) with the focus on the perspective of the dimensions of quality (input, process, and output) in the context of academic degrees, and/or local and international students (Guo \& Guo, 2017). 
An array of studies concluded that quality service is a critical prerequisite and effective tool for establishing and sustaining a satisfying relationship between educational institutions and students (Hasan et al., 2008; Chandra et al., 2019). These studies found quality service to be the antecedent of students' satisfaction, while quality service and students' satisfaction are the antecedents of customers' loyalty. This also indicates that students' satisfaction is the overall experience of students with a service or an educational organization over time (Johnson, Herrmann \& Gustafsson, 2002; Chandra et al., 2019). Students' satisfaction could also be considered as an evaluation of experience with a specific product or service transaction and reactions to it (Olsen \& Johnson, 2003; Khoo, Ha \& McGregor, 2017).

In their studies on the role of service quality in universities, Nazarian, Saber-Mahani and Beheshtifar (2012) noted that the quality of service will affect the satisfaction and behavioral intentions of students positively or negatively. It will also leave positive or negative images in their minds and affects their feelings of satisfaction toward the institutions and their services. The studies of Alnaser and Almsafir (2014) and Azam (2018) also affirmed that the dimensions of ServQual are important for both students and higher education institutions because they will help in the process of monitoring the quality of services received by students and secure the stakeholders' interests. These dimensions were also able to reveal a positive level of satisfaction among students and the number of the unsatisfied group.

Ham and Hayduk (2003) in their study on gaining competitive advantage in high education institutions found a positive correlation between perception of service quality and student's satisfaction. Hasan et al. (2008) and Khoo, Ha and McGregor (2017) concluded that improving service quality can improve students' satisfaction in private higher institutions, while empathy and assurance are the most critical factors of service quality in term of students' satisfaction. Baniya (2016) also reported that empathy and responsiveness are the most preferred dimensions of service quality by students and quality service is an important determinant of students' satisfaction.

Based on the above discussion and looking at the low output of studies on university quality service and satisfaction of international students in Malaysian public universities, the researchers believe that ServQual will help to point out the impact of service quality and its dimensions on international students' satisfaction. The efforts are needed to make the satisfaction level of the international students in Malaysia much better.

\section{Theoretical Framework}

The focus of this study is on the experience of international students in Malaysian public universities of the services they received and the relationship between university quality service and students' satisfaction based on their experiences. This is vital due to the empirical links between effective higher education service and students' satisfaction. The framework used in this study is based on the Gap model of service quality by Parasuraman et al. (1985) which can help in understanding student's satisfaction based on five major gaps that universities must address when seeking to meet students' expectations. As explained in the literature review, the 
service quality gap consists of five dimensions, namely: tangibles, empathy, reliability, assurance, and responsiveness. This gap implies that there is a difference between the expectations of customers and the perception of services.

\section{Figure 1}

\section{Conceptual Framework}

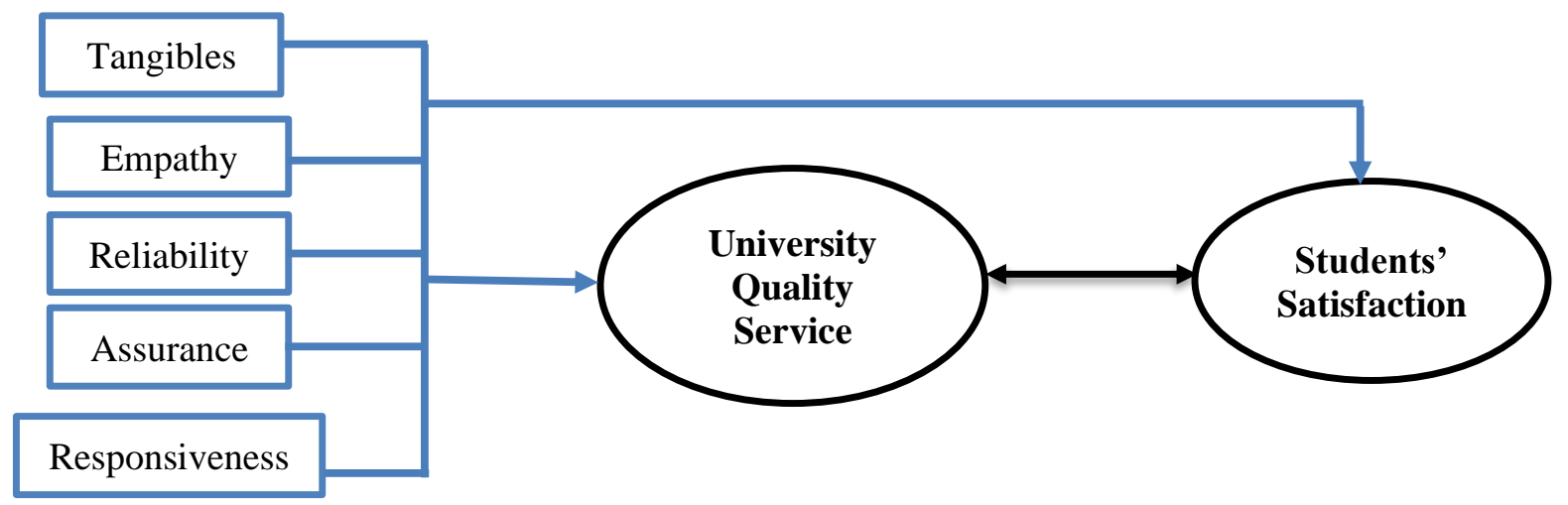

Additionally, the model of customer's satisfaction and trust by Sirdeshmukh, Singh and Sabol (2002) is also important in this study. Its general theory and studies in higher educational institutions indicate that the quality of education service can be a positive and significant predictor of student satisfaction, while satisfaction is a positive predictor of student loyalty (Aritonang, 2014; Annamdevula \& Bellamkonda, 2016; Ongo, Mordekai \& Ochieng, 2019). This study conceptualizes that knowing the existing associations between university quality service, its dimensions, and international students' satisfaction will help universities to realize aspects of improvements and what should be focused on in their efforts to satisfy these students.

Achieving international students' satisfaction will lead to positive loyalty. Loyalty is needed by universities due to the competitiveness of international education and resource scarcity because it will lead to continuous patronage by these students and their close relatives and friends (Aritonang, 2014). Satisfying international students can also help the host nation to enhance its relationship with the students' home countries and international research or academic institutions. Hence, this study proposed the following hypotheses:

H1: There is a relationship between university quality service and international students' satisfaction.

H2: University quality service has a significant impact on international students' satisfaction.

H3: Tangibility has a significant impact on international students' satisfaction.

H4: Empathy has a significant impact on international students' satisfaction.

H5: Reliability has a significant impact on international students' satisfaction.

H6: Assurance has a significant impact on international students' satisfaction.

H7: Responsiveness has a significant impact on international students' satisfaction.

H8: University quality service can predict satisfaction among undergraduate, Master, and $\mathrm{PhD}$ international students. 


\section{METHODODLOGY}

According to the Asia-Pacific Association for International Education (APAIE, 2018) in its regional report, there are about 33,095 international students in number in Malaysia. The population in this study is the international students in Malaysian public universities from countries around the world. They are from Asia, Europe, Middle East, and Africa. The sample size was 1,722 international students in ten (10) Malaysian public universities.

The data was collected through a questionnaire survey based on a 5-Point Likert Scale of (1) strongly disagree, (2) disagree, (3) undecided, (4) agree, and (5) strongly agree. The scales were adapted from ServQual measurement by Parasuraman et al. (1985) and Customer Satisfaction by Sirdeshmukh, Singh and Sabol (2002). The reliability and validity of these scales have been tested and reported by several studies, such as Baniya (2016) and Lien (2017) in their studies on service quality in higher education, and Aritonang (2014) in his student loyalty model. The final scales for university quality service and international students' satisfaction are 36 items. They are tangibles ( 7 items), empathy (6 items), reliability (6 items), assurance (6 items), responsiveness (5 items), and students' satisfaction (6 items) (Table 6).

To assess the internal consistency and reliability of the scale in this study, the Statistical Package for Social Sciences (SPSS) software version 24 was used to compute the Cronbach's alpha. As shown in Table 3, the results showed that the alpha coefficients of all the variables ranged from 0.6 (empathy) to 0.91 (university quality service) as recommended by Ursachi, Horodnic and Zait (2015).

In addition, the analysis approach used in this study is inferential analysis. It is used to estimate the parameters and characteristics of the sample of study based on the given knowledge of the sample's characteristics and the literature from previous studies. This type of analysis is used for establishing the possibility of the existing patterns, relationships, and influence between categories or collectives of a given population based on its sample of study (Blaikie, 2003). In this study, the inferential statistics helped the researchers to test the study's hypotheses through Pearson correlation and regression analyses. It also helped in generating the needed basic descriptive results, such as the means and standard deviations of the variables and items.

\section{RESULTS}

\section{Demographic Data}

The researchers distributed the survey to 1,722 international students and 1,468 surveys were returned from the chosen 10 public universities, which translates to an $85.25 \%$ of response rate. As can be seen in Table 1, the completed surveys were from the international students at the International Islamic University Malaysia (IIUM, n=270), University Utara Malaysia (UUM, $\mathrm{n}=211$ ), Universiti Teknologi Malaysia (UTM, n=202), Universiti Sains Malaysia (USM, $\mathrm{n}=187$ ), University of Malaya (UM, $\mathrm{n}=161$ ), University Putra Malaysia (UPM, $\mathrm{n}=119$ ), Universiti Sains Islam Malaysia (USIM, n=100), Universiti Kebangsaan Malaysia (UKM, 
$\mathrm{n}=88$ ), Universiti Sultan Zainal Abidin/Universiti Malaysia Terengganu (UNISZA, $\mathrm{n}=73$ ), and Universiti Pendidikan Sultan Idris (UPSI, n=57).

\section{Table 1}

Demographics of Respondents

\begin{tabular}{|c|c|c|c|c|c|c|c|c|}
\hline \multicolumn{3}{|c|}{ Name of University } & \multicolumn{3}{|c|}{ Continents of Students } & \multicolumn{3}{|c|}{ Students' Academic Level } \\
\hline University & Frequency & Percent & Continent & Frequency & Percent & Program & Frequency & Percent \\
\hline IIUM & 270 & 18.4 & Asia & 947 & 64.5 & $\mathrm{PhD}$ & 601 & 40.9 \\
\hline UUM & 211 & 14.4 & Africa & 488 & 33.2 & Master & 487 & 33.2 \\
\hline UTM & 202 & 13.8 & Americas & 15 & 1 & Undergraduate & e380 & 25.9 \\
\hline USM & 187 & 12.7 & Europe & 14 & 1 & Total & 1468 & 100.0 \\
\hline UM & 161 & 11 & Australia & 4 & 0.3 & & & \\
\hline UPM & 119 & 8.1 & Total & 1468 & 100.0 & & & \\
\hline USIM & 100 & 6.8 & & & & & & \\
\hline UKM & 88 & 6 & \multicolumn{3}{|c|}{ Gender of Student } & & & \\
\hline UNISZA & 73 & 5 & Male & 1017 & 69.3 & & & \\
\hline UPSI & 57 & 3.9 & Female & 451 & 30.7 & & & \\
\hline Total & 1468 & 100.0 & Total & 1468 & 100.0 & & & \\
\hline
\end{tabular}

The participants who completed the survey questionnaire are 1,468 international students studying in 10 different Malaysian public universities between 2019 and 2020. Table 1 shows that majority of the respondents were from Asia $(n=947,64.5 \%)$ followed by Africa $(n=488$, $33.2 \%)$, America $(n=15,1.0 \%)$, Europe $(n=14,1.0 \%)$, and Australia $(n=4,0.3 \%)$. In term of gender, $69.3 \%(n=1017)$ of the participants were males and $30.7 \%(n=451)$ of them were females due to the high population of male foreign students in Malaysian universities. This demographic also reflects the reality of countries of international students in Malaysia. They are mostly from Asia because of the similarity in culture, followed by Africa due to the relatively low cost of degree programs in some Malaysian public higher institutions.

\section{Students' Satisfaction towards University Quality Service}

Descriptive analysis based on items' regression (dependent variable: satisfaction) was run to check the level of international students' satisfaction toward university quality service in Malaysian public universities. As presented in Table 2 below, the standard deviations (SD) of the variables and items cannot be categorized as "good" or "bad" because they are indicators of how spread out the data is, although the results showed that the SDs are below the mean scores and are between the range of 0.60 and 0.85 . Also, students' satisfaction (dependent variable) has a mean score of 3.53 (on a 5-point scale), while university quality service (independent variable) has a mean score of 3.45. These mean scores indicated that, in general, there are moderate positive perceptions of university quality service and students' satisfaction. It could also be seen as an indication that international students are satisfied with the overall university service quality. 
For the satisfaction of students toward the dimensions of university quality service, Table 2 shows that tangibles scored the highest (3.63 mean score) followed by responsiveness (3.62 mean score), reliability (3.53 mean score), assurance (3.45 mean score), and empathy (3.04 mean score). Based on the descriptive results in Table 3, tangibles also have the item with the highest mean score (item 5), while empathy has the item with the lowest mean score (item 12). Thus it could be said that the international students are more satisfied with the tangibility of university quality service, while they're least satisfied with its empathy.

\section{Table 2}

Results of Descriptive Statistics of Items' Regression (DV: Satisfaction)

\begin{tabular}{|c|c|c|c|}
\hline \multirow{2}{*}{ No } & Items & \multirow{2}{*}{ Mean } & \multirow{2}{*}{$\mathrm{SD}$} \\
\hline & University Quality Service & & \\
\hline & Tangibles & 3.63 & 0.65 \\
\hline 1 & $\begin{array}{l}\text { Modern facilities (e.g. academic building, sport, health and } \\
\text { accommodation) are provided in my university. }\end{array}$ & 3.84 & 1.09 \\
\hline 2 & My university possesses a suitable location. & 3.75 & 1.07 \\
\hline 3 & $\begin{array}{l}\text { The facilities in my university are enough for the international students' } \\
\text { population. }\end{array}$ & 3.60 & 1.08 \\
\hline 4 & $\begin{array}{l}\text { The educational resources provided by my university are useful for } \\
\text { academic growth. }\end{array}$ & 3.84 & .995 \\
\hline 5 & My university environment is visually pleasing. & 3.88 & 1.04 \\
\hline 6 & $\begin{array}{l}\text { Signs around the university campus are written in both Bahasa Melayu } \\
\text { and English. }\end{array}$ & 2.77 & 1.35 \\
\hline \multirow[t]{2}{*}{7} & The information in the signs is helpful. & 3.75 & 1.06 \\
\hline & Empathy & 3.04 & 0.68 \\
\hline 8 & $\begin{array}{l}\text { Students are notified in a timely way about the important schedules, } \\
\text { examinations, and events. }\end{array}$ & 3.79 & 1.03 \\
\hline 9 & $\begin{array}{l}\text { My university puts international students' academic development as one } \\
\text { of their top priorities. }\end{array}$ & 2.80 & 1.19 \\
\hline 10 & $\begin{array}{l}\text { University staff/management gives emotional support to international } \\
\text { students. }\end{array}$ & 2.41 & 1.52 \\
\hline 11 & Classes hours or periods are convenient for all students. & 3.57 & 1.05 \\
\hline 12 & $\begin{array}{l}\text { In my university, I feel that local and international students are treated } \\
\text { equally. }\end{array}$ & 2.24 & 1.42 \\
\hline \multirow[t]{2}{*}{13} & $\begin{array}{l}\text { When I have a problem related to my academic issues, a member of the } \\
\text { university will help me to solve it. }\end{array}$ & 3.44 & 1.11 \\
\hline & Reliability & 3.53 & 0.78 \\
\hline 14 & My university implements a consistent academic fee structure. & 3.52 & 1.12 \\
\hline 15 & My university performs the right service all the time. & 3.42 & 1.13 \\
\hline 16 & My university provides service at the time it promises to do so. & 3.57 & 1.07 \\
\hline 17 & $\begin{array}{l}\text { My university practices good records management (e.g. admission, } \\
\text { assessment, results, and financial records). }\end{array}$ & 3.48 & 1.13 \\
\hline 18 & $\begin{array}{l}\text { My university provides academic consultation services for the students } \\
\text { who need them. }\end{array}$ & 3.54 & 1.08 \\
\hline
\end{tabular}




\section{Table 2}

Continued

\begin{tabular}{|c|c|c|c|}
\hline \multirow{2}{*}{ No } & Items & \multirow{2}{*}{ Mean } & \multirow{2}{*}{ SD } \\
\hline & University Quality Service & & \\
\hline \multirow[b]{2}{*}{19} & Reliability & 3.53 & 0.78 \\
\hline & $\begin{array}{l}\text { My university assigns a supervisor who can help me to achieve } \\
\text { academically }\end{array}$ & 3.65 & 1.10 \\
\hline & Assurance & 3.45 & 0.72 \\
\hline 20 & My lecturers encourage all students to do well in their studies. & 3.70 & 1.10 \\
\hline 21 & As an international student, I feel respected. & 2.55 & 0.65 \\
\hline 22 & I find the academic staff courteous to international students. & 3.59 & 1.154 \\
\hline 23 & $\begin{array}{l}\text { I find my lecturers able to answer my academic questions in class or } \\
\text { anytime I approach them. }\end{array}$ & 3.63 & 1.15 \\
\hline 24 & $\begin{array}{l}\text { My lecturers make me feel confident in my ability to complete my } \\
\text { coursework. }\end{array}$ & 3.64 & 1.11 \\
\hline \multirow[t]{2}{*}{25} & The criteria of the answer scheme are clearly explained by my lecturers. & 3.60 & 1.12 \\
\hline & Responsiveness & 3.62 & 0.81 \\
\hline 26 & $\begin{array}{l}\text { My university international affairs act immediately on international } \\
\text { students' demands (e.g. academic/service/research). }\end{array}$ & 3.60 & 1.09 \\
\hline 27 & My department administrators are helpful. & 3.64 & 1.12 \\
\hline 28 & $\begin{array}{l}\text { When I have a problem with the university services, the university } \\
\text { administrators/technicians help to solve the problem on time. }\end{array}$ & 3.58 & 1.11 \\
\hline 29 & $\begin{array}{l}\text { I receive prompt responses when I call the university offices for urgent } \\
\text { matters (e.g. research/academic/thesis). }\end{array}$ & 3.57 & 1.13 \\
\hline \multirow[t]{3}{*}{30} & My lecturers are always willing to help me. & 3.68 & 1.14 \\
\hline & International Students' Satisfaction & & \\
\hline & Satisfaction & 3.53 & 0.85 \\
\hline 31 & I am satisfied with the overall quality of my university services. & & \\
\hline 32 & $\begin{array}{l}\text { I am satisfied with the university compared with other universities outside } \\
\text { Malaysia (e.g., fees, research, and supervision). }\end{array}$ & & \\
\hline 33 & I choose the right choice by studying my course at this university. & & \\
\hline 34 & I talk positively about my course to others. & & \\
\hline 35 & My university is ranked worldwide. & & \\
\hline 36 & My university has a good image outside Malaysia. & & \\
\hline
\end{tabular}

Also, Table 2 of the mean scores of all items indicated that international students are more satisfied with some aspects of quality service, such as a visually pleasing study environment (item 5, mean score: 3.88), modern facilities (item 1, mean score: 3.84), timely notification of important schedules, examinations and events (item 8, mean score: 3.79), and lecturers encouragement and motivation for students to do well in their studies (item 20, mean score: 3.70).

Conversely, the low mean scores of some items indicated that the majority of international students think that university quality service still needs serious improvements. This can be seen in item 12 which has the lowest mean score of 2.24, hence shows an unsatisfactory level on how the international students are treated by the universities compared to the local students, 
followed by item 10 (university staff/management gives emotional support to international students) with a mean score of 2.41; item 21 (as an international student, I feel respected) with a mean score of 2.55; item 6 (signs around the university campus are written in both Bahasa Melayu and English) with a mean score of 2.77, and item 9 (My university puts international students' academic development as one of their top priorities) with a mean score of 2.80 .

\section{Relationship between Quality Service, Its Dimensions and Students' Satisfactions}

Pearson correlation was run to check the relationship between quality service and students' loyalty. The correlation matrix in Table 3 shows that university quality service was significantly and positively related to international students' satisfaction ( $\mathrm{r}=0.66, \mathrm{p}<0.001)$. This also means that there is a strong relationship between overall university quality service and students' satisfaction.

\section{Table 3}

Correlation Matrix and Cronbach's Alpha

\begin{tabular}{clccccccc}
\hline No & Variable/Factors & 1 & 2 & 3 & 4 & 5 & 6 & 7 \\
\hline 1 & Satisfaction & 0.85 & & & & & & \\
2 & UQuality Service & $0.66^{* *}$ & 0.91 & & & & & \\
3 & Tangibles & $0.56^{* *}$ & $0.80^{* *}$ & 0.70 & & & & \\
4 & Empathy & $0.46^{* *}$ & $0.75^{* *}$ & $0.52^{* *}$ & 0.60 & & & \\
5 & Reliability & $0.56^{* *}$ & $0.88^{* *}$ & $0.61^{* *}$ & $0.59^{* *}$ & 0.80 & & \\
6 & Assurance & $0.57^{* *}$ & $0.84^{* *}$ & $0.58^{* *}$ & $0.48^{* *}$ & $0.70^{* *}$ & 0.76 & \\
7 & Responsiveness & $0.56^{* *}$ & $0.86^{* *}$ & $.582^{* *}$ & $0.56^{* *}$ & $0.71^{* *}$ & $0.71^{* *}$ & 0.78
\end{tabular}

Note. ${ }^{* *}$ Correlation is significant at the 0.01 level (2-tailed).

Cronbach's alpha values are shown in diagonal

Table 3 also shows significant and positive results for the relationship between international students' satisfaction and dimensions of university quality service. Satisfaction has the highest relationship with assurance $(\mathrm{r}=0.57, \mathrm{p}<0.001)$. The correlation matrix also indicated that assurance, followed by tangibles, reliability, and responsiveness, all have strong relationships with satisfaction, while empathy has the lowest relationship ( $r=0.46, p<0.001)$. Moreover, all the dimensions of university quality service are highly correlated with each other, except for assurance which scored low but still significant $(r=0.48, \mathrm{p}<0.001)$ in its relationship with empathy. Hence, responsiveness, tangibles, and reliability are highly correlated and significant with one another.

\section{Impact of University Quality Service on Student's Satisfaction}

Regression analyses were used to check the impact of quality service and its dimensions on international students' satisfaction. They were also used to check whether university quality service can predict international students' satisfaction and the critical variables or dimensions of service quality based on the experiences of international students in Malaysian public universities. Table 4 shows that the results of the simple regression analysis showed that 
university quality service, in general, explained $43.3 \%$ of the variance in international students' satisfaction $\left(\mathrm{R}^{2}=0.43, \mathrm{~F}(1,468)=1120.05, \mathrm{p}<0.001\right)$. It was found that university quality service significantly predicted satisfaction $(\beta=0.94, \mathrm{p}<0.001)$. Based on these results, it could also be said that university quality service is an antecedent of international students' satisfaction in Malaysian public universities.

Table 4

Simple Linear Regression Analyses Results

\begin{tabular}{|c|c|c|c|c|c|c|}
\hline \multicolumn{7}{|c|}{ Coefficients $^{\mathrm{a}}$} \\
\hline & \multirow[t]{2}{*}{ Model } & \multicolumn{2}{|c|}{$\begin{array}{l}\text { Unstandardized } \\
\text { Coefficients }\end{array}$} & \multirow{2}{*}{$\begin{array}{l}\text { Standardized } \\
\text { Coefficients }\end{array}$} & \multirow[t]{2}{*}{$\mathrm{t}$} & \multirow[t]{2}{*}{ Sig. } \\
\hline & & $\beta$ & Std. Error & & & \\
\hline \multirow[t]{2}{*}{1} & (Constant) & 0.29 & 0.10 & & 3.00 & .003 \\
\hline & UQuality_Service & 0.94 & 0.03 & 0.66 & 33.48 & .000 \\
\hline \multicolumn{7}{|c|}{ Model Summary } \\
\hline & & & $\mathrm{R}^{2}$ & Adjusted $\mathrm{R}^{2}$ & $\mathrm{~F}$ & $\mathrm{~N}$ \\
\hline 1 & UQuality Service & & .43 & 0.43 & $1120.05^{* *}$ & 1,468 \\
\hline
\end{tabular}

Note. Dependent Variable: Student Satisfaction; $* * \mathrm{p}<0.001$

Table 5 presents multiple regression results for the impact of quality service dimensions on international students' satisfaction. It indicates that $44.8 \%$ of the variance in international students' satisfaction was explained by the five dimensions of university quality service $\left(\mathrm{R}^{2}=\right.$ $0.44, \mathrm{~F}(1,468)=227.98, \mathrm{p}<0.001)$. It was found that tangibles significantly predicted satisfaction $(\beta=0.30, p<0.001)$, followed by assurance $(\beta=0.23, p<0.001)$, reliability $(\beta=0.14, p<0.001)$, empathy $(\beta=0.12, \mathrm{p}<0.001)$, and responsiveness $(\beta=0.16, \mathrm{p}<0.001)$.

Table 5

General Multiple Regression Analyses Results

\begin{tabular}{|c|c|c|c|c|c|c|}
\hline \multicolumn{7}{|c|}{ Coefficients $^{\mathrm{a}}$} \\
\hline & \multirow{3}{*}{ Model } & \multirow{2}{*}{\multicolumn{2}{|c|}{$\begin{array}{l}\text { Unstandardized } \\
\text { Coefficients }\end{array}$}} & \multirow{3}{*}{$\begin{array}{l}\text { Standardized } \\
\text { Coefficients }\end{array}$} & \multirow{3}{*}{$\mathrm{t}$} & \multirow{3}{*}{ Sig. } \\
\hline & & & & & & \\
\hline & & B & Std. Error & & & \\
\hline \multirow[t]{6}{*}{1} & (Constant) & 0.23 & 0.10 & & 2.22 & .026 \\
\hline & Tangibles & 0.30 & 0.035 & $0.23 * *$ & 8.66 & .000 \\
\hline & Empathy & 0.12 & 0.032 & $0.09 * *$ & 3.61 & .000 \\
\hline & Reliability & 0.14 & 0.035 & $0.13 * *$ & 3.90 & .000 \\
\hline & Assurance & 0.23 & 0.037 & $0.20 * *$ & 6.35 & .000 \\
\hline & Responsiveness & 0.16 & 0.033 & $0.15 * *$ & 4.75 & .000 \\
\hline \multicolumn{7}{|c|}{ Model Summary } \\
\hline & & \multicolumn{2}{|c|}{$\mathrm{R}^{2}$} & Adjusted $\mathrm{R}^{2}$ & $\mathrm{~F}$ & $\mathrm{~N}$ \\
\hline 1 & & \multicolumn{2}{|c|}{0.44} & 0.44 & $227.98 * *$ & 1,468 \\
\hline
\end{tabular}

Note. Dependent Variable: Student Satisfaction; ** $\mathrm{p}<0.001$ 
Based on the results in Table 5 above, all dimensions of quality service are statistically significant, while tangibles and assurance are even more significant than others. Thus, it could be said that while all the five dimensions are important components of quality service that contributed to international students' satisfaction, tangibles and empathy are the two most critical components.

The researchers also ran multiple regression analyses based on the degree programs of the international students to check whether university quality service can predict and impact international students' satisfaction with each academic program. The results in Table 6 showed that for the undergraduate program, $24.8 \%$ of the variance in students' satisfaction was explained by university quality service $\left(R^{2}=0.24, F(380)=119.531, p<0.001\right)$. It was also found that for the undergraduate program university quality service significantly predicted satisfaction $(\beta=0.60, p<0.001)$. Thus, quality service can be perceived as an antecedent of the satisfaction of undergraduate international students in Malaysian public universities.

Table 6

Multiple Regression Results based on Students' Academic Degrees

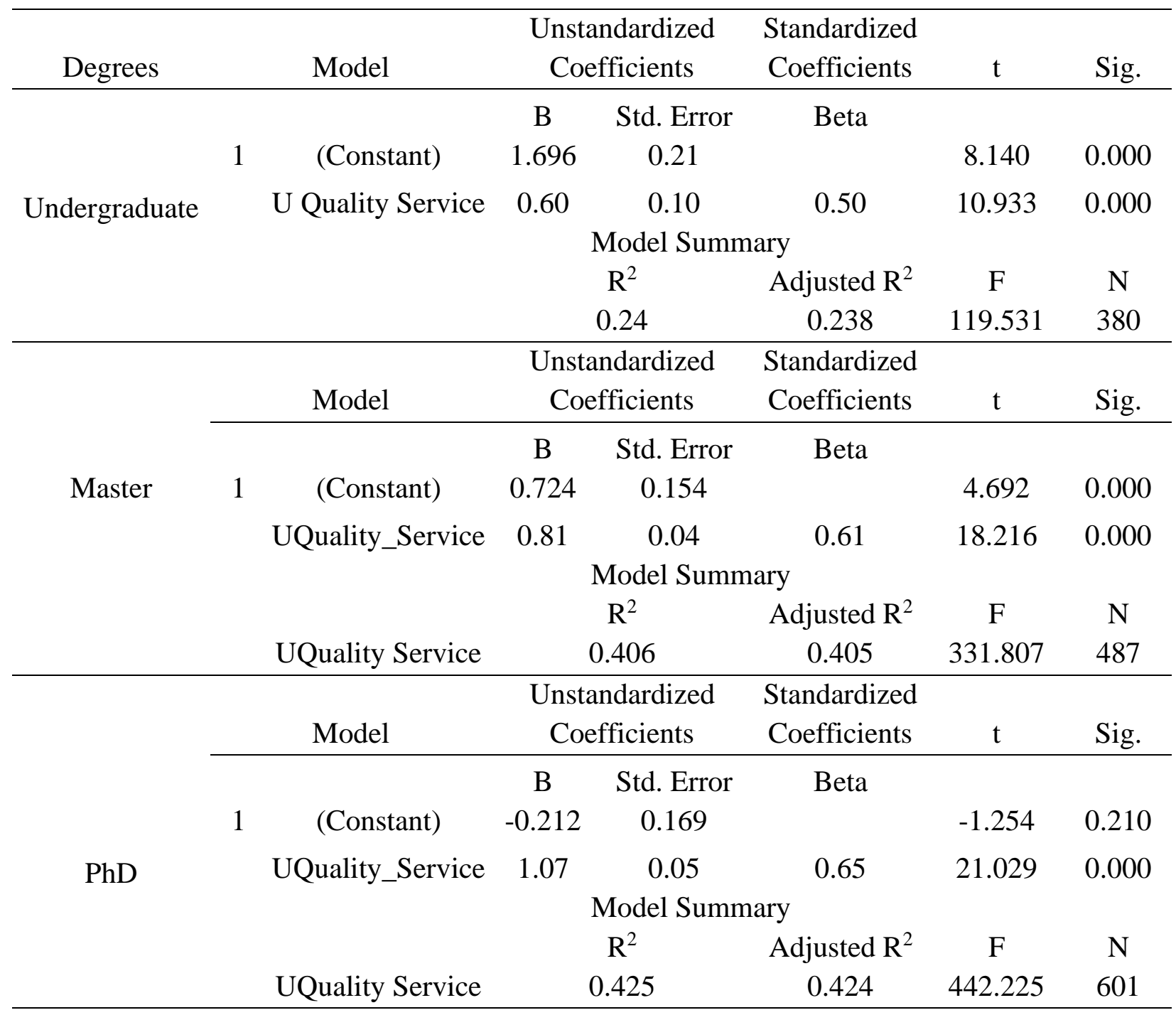

Note. Dependent Variable: Student Satisfaction; $* * \mathrm{p}<0.001$ 
For the international students in their Master's degree program, Table 6 shows that $40.6 \%$ of the variance in students' satisfaction was explained by university quality service $\left(\mathrm{R}^{2}=0.406\right.$, $\mathrm{F}(487)=331.807, \mathrm{p}<0.001)$. It was found that university quality service significantly predicted satisfaction for a Master's degree program $(\beta=0.81, \mathrm{p}<0.001)$. These results also indicated that quality service is an antecedent of the satisfaction of Master students in Malaysian public universities.

For $\mathrm{PhD}$ students, Table 6 shows that $42 \%$ of the variance in international students' satisfaction was explained by university quality service $\left(R^{2}=0.425, F(601)=442.225, p<0.001\right)$. University quality service was found to significantly predict satisfaction for $\mathrm{PhD}$ students $(\beta=$ $1.07, \mathrm{p}<0.001)$. Hence, it can be concluded that quality service is an antecedent of $\mathrm{PhD}$ students' satisfaction in Malaysian public universities.

Finally, Table 7 presents all the hypotheses supported by the correlation and regression analyses results. It shows that all the hypotheses are significant.

\section{Table 7}

\section{Hypotheses Presentation}

\begin{tabular}{|c|c|c|}
\hline Hypotheses & Results & Conclusion \\
\hline $\begin{array}{l}\text { There is a relationship between university } \\
\text { quality service and international students' } \\
\text { satisfaction. }\end{array}$ & $\begin{array}{l}\text { Yes: }(r=0.66, p<0.001) \\
\text { Significant }\end{array}$ & Supported \\
\hline $\begin{array}{l}\text { H1: University quality service has a } \\
\text { significant impact on international students' } \\
\text { satisfaction. }\end{array}$ & $\begin{array}{l}\text { Yes: }\left(\mathrm{R}^{2}=0.43, \mathrm{p}<0.001\right) \\
\text { Significant }\end{array}$ & Supported \\
\hline $\begin{array}{l}\text { H2: Quality service dimensions have } \\
\text { significant impacts on international students' } \\
\text { satisfaction. } \\
\text { Tangibles } \\
\text { Empathy } \\
\text { Assurance. } \\
\text { Reliability } \\
\text { Responsiveness. }\end{array}$ & $\begin{array}{l}\text { Yes. Significant } \\
\left(\mathrm{R}^{2}=0.44, \mathrm{p}<0.001\right) \\
(\beta=0.30, \mathrm{p}<0.001) \\
(\beta=0.12, \mathrm{p}<0.001) \\
(\beta=0.23, \mathrm{p}<0.001) \\
(\beta=0.14, \mathrm{p}<0.001) \\
(\beta=0.16, p<0.001)\end{array}$ & Supported \\
\hline $\begin{array}{l}\text { H3: University quality service can predict } \\
\text { satisfaction among undergraduate, master, } \\
\text { and PhD international students }\end{array}$ & Yes. Significant & Supported \\
\hline Undergraduate & $\begin{array}{l}\left(R^{2}=0.24, F(380)=119.531\right. \\
(\beta=0.60, p<0.001)\end{array}$ & \\
\hline Master & $\begin{array}{l}\left(\mathrm{R}^{2}=0.406, \mathrm{~F}(487)=\right. \\
331.807, \beta=0.81, \mathrm{p}<0.001)\end{array}$ & \\
\hline $\mathrm{PhD}$ & $\begin{array}{l}\left(R^{2}=0.425,\right. \\
F(601)=442.225, \quad \beta=1.07, \\
p<0.001)\end{array}$ & \\
\hline
\end{tabular}




\section{DISCUSSION}

This study focused on the satisfaction of international students toward the quality service of Malaysian public universities they have received. It also examined the relationship between quality service, its dimensions, and students' satisfaction. While the study checked the critical components in university quality service that contribute mostly to international students' satisfaction, it also examined the impact of quality service and its dimensions on students' satisfaction.

Firstly, the descriptive results revealed that the overall satisfaction of international students' satisfaction towards quality service of Malaysian public universities is moderate. They are more satisfied with the tangibles of university service, but least satisfied with the aspects of empathy. This is consistent with the studies of Abdullah (2006) and Ali et al. (2016). The findings also echoed the results of Gregory (2019) on the low level of satisfaction with empathy and assurance due to an emotional disconnect between educational administrators and university's staffs, knowledge and courtesy, the feelings of uncertainty by the students about their programs, and not being respected. Ibrahim, Wang and Hassan (2013) signaled the need to focus more on the reliability and assurance of educational services provided to the international students, with even greater attention to the foreign students' emotional aspects and prompt staff's responses/feedbacks to them.

Secondly, the findings showed that there is a significant relationship between overall university quality service and international students' satisfaction. In this study, the correlation is higher but still in line with the study of Baniya (2016). This current study showed that all the dimensions of quality service have positive and moderate significant relationships with satisfaction. It also indicated that assurance, tangibles, reliability, and responsiveness are key determinants of quality service and students' satisfaction, while tangibles and empathy are the most critical components. This supports the findings of previous studies that despite the usefulness of quality service dimensions in the educational sector, some components will be significant than others (Soutar \& McNiel, 1996; Abdullah, 2006; Ongo, 2019). The current study also found that international students in their satisfactions with higher education are more concerned about the issues of human connection, trust, confidence, and staff knowledge. It also showed that tangibles of an educational institution such as facilities and infrastructures can have a direct impact on students' service quality perceptions.

Finally, this study found that university quality service can predict international students' satisfaction. Quality service is also an antecedent of the satisfaction of undergraduate, Master's, and PhD students in Malaysian public universities. This is in line with Baniya's (2016) study, even though the results of the current study showed that $\mathrm{PhD}$ has the highest coefficient $\left(\mathrm{R}^{2}=0.42\right.$, adjusted $\left.\mathrm{R}^{2}=0.43\right)$ which could be because of its high population size $(\mathrm{N}=601)$, followed by Masters $(\mathrm{R} 2=0.40$, adjusted $\mathrm{R} 2=0.40$ ) with the population size of $\mathrm{N}=487$, and undergraduates $(\mathrm{R} 2=0.24$, adjusted $\mathrm{R} 2=0.24)$ which has the lowest number of population $(\mathrm{N}=380)$. Thus, there is a need for further research with an equal data size among the degree programs. 


\section{CONCLUSION}

This study concludes that the dimensions of service quality are useful in measuring the level of international students' satisfaction toward university service. The findings of this study proved that quality service and its dimensions are positively related to student satisfaction, while the satisfaction level of international students is moderate and positive but not high enough. There is a need to improve the ability to perform the promised/advertised service in reliable way. The academic and non-academic offices also need to adjust the politeness of their staff to inspire confidence and trust. Furthermore, the emotional aspects of the service should be put into consideration. It should be noted that what the international students might consider nonessentials of quality service might be among the necessities of quality service in the opinion of local students. Consequently, this study adds to the growing body of knowledge on international education and foreign students' satisfaction that could lead to securing these students' loyalty, thus aid academics and non-academics in their quest to increase the number of international students' enrolments and meet up their expectations. 


\section{REFERENCES}

Abdullah, D., Abd Aziz, M. I., \& Mohd Ibrahim, A. L. (2017). The stories they tell: Understanding international student mobility through higher education policy. Journal of Studies in International Education, 21(5), 450-466.

Abdullah, F. (2006). Measuring service quality in higher education: HEdPERF versus SERVPERF. Marketing Intelligence and Planning, 24(1), 31-47.

Albayrak, T. (2019). The inclusion of competitor information in the three-factor theory of customer satisfaction. International Journal of Contemporary Hospitality Management, 31(4), 1924-1936.

Ali, F., Zhou, Y., Hussain, K., Nair, P. K., \& Ragavan, N. A. (2016). Does higher education service quality effect student satisfaction, image, and loyalty? A study of international students in Malaysian public universities. Quality Assurance in Education, 24(1), 70-94.

Alnaser, F., Ghani, M., \& Rahi, M. (2017). The Impact of SERVQUAL Model and Subjective Norms on Customer's Satisfaction and Customer Loyalty in Islamic Banks: A Cultural Context. International Journal of Economics \& Management Sciences, 6(5), 1000455.

Annamdevula, S., \& Bellamkonda, R. S. (2016). The effects of service quality on student loyalty: The mediating role of student satisfaction. Journal of Modelling in Management, 11(2), 446-462.

Aritonang, R. L. (2014). Student loyalty modelling. Market-Tržište, 26(1), 77-91.

Asia-Pacific Association for International Education (APAIE). (2018). Recent Development of International Higher Education in Malaysia: Regional Reports. Retrieved from https://www.apaie2018.org/sites/default/files/Speaker\%20Slides/Recent\%20Developme nt\%20of\%20International\%20Higher\%20Education\%20in\%20Malaysia.pdf

Azam, A. (2018). Service Quality Dimensions and Students' Satisfaction: A study of Saudi Arabian Private Higher Education Institutions. European Online Journal of Natural and Social Sciences, 7(2), 275-284.

Baniya, R. (2016). Relationship between perception of service quality and students' satisfaction-a case study of a management school. Journal of Education and Research, 6(2), 41-60.

Blaikie, N. (2003). Inferential analysis: from sample to population. London: SAGE Publications Ltd.

Borgave, S. (2012). Service Quality Management: A Literature Review. STE's Sinhgad Institute of Business Administration \& Computer Application, Kusagon. Research Gate Retrieved September 10, 2020 from https://www.researchgate.net/publication/274332133_ SERVICE_QUALITY_MANAGEMENT_A_LITERATURE_REVIEW

Cardozo, R. (1965). An Experimental Study of Customer Effort, Expectation, and Satisfaction. Journal of Marketing Research, 2(3), 244-249.

Carey, K., Cambiano, R. L., \& De Vore, J. B. (2002, July). Student to faculty satisfaction at a Midwestern university in the United States. In The $25^{\text {th }}$ HERSDA Annual Conference. 
Chandra, T., Hafni, L., Chandra, S., Purwati, A. A., \& Chandra, J. (2019). The influence of service quality, university image on student satisfaction and student loyalty. Benchmarking: An International Journal, 26(5), 1533-1549.

Clayson, D. E., \& Haley, D. A. (2005). Marketing models in education: Students as customers, products or partners. Marketing Education Review, 15(1), 1-10.

Deming, W. E., \& Edwards, D. W. (1982). Quality, productivity, and competitive position (Vol. 183). Cambridge, MA: Massachusetts Institute of Technology, Center for Advanced Engineering Study.

Gerson, R. (1993). Measuring customer satisfaction. Crisp Learning.

Gregory, J. L. (2019). Applying SERVQUAL: Using service quality perceptions to improve student satisfaction and program image. Journal of Applied Research in Higher Education, 11(4), 788-799.

Grönroos, C. (1984). A Service Quality Model and its Marketing Implications. European Journal of Marketing, 18(4), 36-44

Guo, Y., \& Guo, S. (2017). Internationalization of Canadian higher education: Discrepancies between policies and international student experiences. Studies in Higher Education, 42(5), 851-868.

Ham, L., \& Hayduk, S. (2003). Gaining competitive advantage in higher education: Analyzing the gap between expectations and perceptions of service quality. International Journal of Value-Based Management, 16, 223-242.

Hanaysha, J. R., Abdullah, H. H., \& Warokka, A. (2011). Service quality and students' satisfaction at higher learning institutions: The competing dimensions of Malaysian universities' competitiveness. The Journal of Southeast Asian Research, 1-10.

Hasan, H. F. A., Ilias, A., Rahman, R. A., \& Razak, M. Z. A. (2008). Service quality and student satisfaction: A case study at private higher education institutions. International Business Research, 1(3), 163-175.

He, X., Huang, S. Z., Li, T., \& Chen, K. K. (2017). A Study of Interactive Style on Students Loyalty in Science Technology Education: Moderating of Management Level. Eurasia Journal of Mathematics, Science and Technology Education, 13(8), 4689-4700.

Howard, J. A., \& Sheth, J. N. (1969). The Theory of Buyer Behavior. New York, NY: John Wiley.

Jain, R., Aagja, J., \& Bagdare, S. (2017). Customer experience: A review and research agenda. Journal of Service Theory and Practice, 27(3), 642-662.

Johnson, M. D., Herrmann, A., \& Gustafsson, A. (2002). Comparing customer satisfaction across industries and countries. Journal of Economic Psychology, 23(6), 749-769.

Juran, J. M. (1974). Juran's Quality Control Handbook ( $3^{\text {rd }}$ Edition). New York, NY: McGrawHill. 
Kasiri, L. A., Cheng, K. T. G., Sambasivan, M., \& Sidin, S. M. (2017). Integration of standardization and customization: Impact on service quality, customer satisfaction, and loyalty. Journal of Retailing and Consumer Services, 35(1), 91-97.

Khoo, S., Ha, H., \& McGregor, S. L. T. (2017). Service quality and student/customer satisfaction in the private tertiary education sector in Singapore. International Journal of Educational Management, 31(4), 430-444.

Kotler, P., \& Clarke, R. N. (1987). Marketing for health care organizations. Englewood Cliffs, NJ: Prentice-Hall.

Lien, P. T. (2017). Training service quality and its effects on student satisfaction: Case of a Vietnam University. International Journal of Academic Research in Business and Social Sciences, 7(4), 99-110.

Malik, M. E., Danish, R. Q., \& Usman, A. (2010). The impact of service quality on students' satisfaction in higher education Institutes of Punjab. Journal of Management Research, 2(2), 1-11.

Ministry of Higher Education (MOHE). (2007). National Higher Education Strategic Plan Beyond 2020. Putrajaya: Ministry of Higher Education Malaysia.

Nazarian, R., Saber-Mahani, M., \& Beheshtifar, M. (2012). Role of Service Quality in Universities. Innova Ciencia, 4(6), 3-9.

OECD. (2015). Education at a Glance 2015: OECD Indicators. Paris: OECD Publishing. https://doi.org/10.1787/eag-2015-en. Accessed 12 August 2020.

Ok, S., Suy, R., Chhay, L., \& Choun, C. (2018). Customer satisfaction and service quality in the marketing practice: Study on literature review. Asian Themes in Social Sciences Research, 1(1), 21-27.

Oldfield, B. M., \& Baron, S. (2000). Student Perceptions of Service Quality in a UK University Business and Management Faculty. Quality Assurance in Education, 8, 85-95.

Oliver, R. L. (1977). Effect of expectation and disconfirmation on postexposure product evaluations: An alternative interpretation. Journal of Applied Psychology, 62(4), 480486.

Olsen, L. L., \& Johnson, M. D. (2003). Service equity, satisfaction, and loyalty: From transaction-specific to cumulative evaluations. Journal of Service Research, 5(3), 184195.

Ongo, M. O. (2019). Examining Perceptions of Service Quality of Student Services and Satisfaction Among International Students at Universities in Indiana and Michigan. Dissertations 1675, https://digitalcommons.andrews.edu/dissertations/1675 Accessed 20 August 2020.

Parasuraman, A., Zeithaml, Valerie A. \& Berry, Leonard, L. (1985). A conceptual model of service quality and its implications for future research. Journal of Marketing, 49(1), 4150 . 
Ratnasari, R. T., Gunawan, S., Septiarini, D. F., Rusmita, S. A., \& Kirana, K. C. (2020). Customer satisfaction between perceptions of environment destination brand and behavioral intention. International Journal of Innovation, Creativity and Change, 10(12), 472-487.

Rowley, J. E. (1996). Customer compatibility management: An alternative perspective on student-to-student support in higher education. International Journal of Educational Management, 10(4), 15-20.

Shokouhyar, S., Shokoohyar, S., \& Safari, S. (2020). Research on the influence of after-sales service quality factors on customer satisfaction. Journal of Retailing and Consumer Services, 56(1), 102139.

Soutar, G., \& McNeil, M. (1996). Measuring service quality in a tertiary institution. Journal of Educational Administration, 34(1), 72-82.

Stacey, V. (2019). Malaysia to recalibrate its strategy as 200k int'l student target by 2020 looks unlikely. The Pie News. Retrieved 20 March, 2020 from https://thepienews.com /news/malaysia-to-recalibrate-strategy-as-200000-target-looks-out-of-reach/.

Sun, Y. N., \& Gao, Q. (2015). Research on the Influence Factors of the Service Satisfaction in University Campuses in China: A Review. Open Journal of Social Sciences, 3, 262-270.

Ursachi, G., Horodnic, I. A., \& Zait, A. (2015). How reliable are measurement scales? External factors with indirect influence on reliability estimators. Procedia Economics and Finance, 20, 679-686.

Westbrook, R. A. (1981). Sources of consumer satisfaction with retail outlets. Journal of Retailing, 57(3), 68-85.

Zammuto, R. F., Keaveney, S. M., \& O'Connor, E. J. (1996). Rethinking student services: Assessing and improving service quality. Journal of Marketing for Higher Education, 7(1), 45-70.

Zeithaml, V. A., \& Gilly, M. C. (1987). Characteristics affecting the acceptance of retailing technologies: A comparison of elderly and nonelderly consumers. Journal of Retailing, 63(1), 49-68. 